\title{
Risk management and risk management performance measurement in the con- struction projects of Finland
}

\author{
Mohammad Shakilur Rahman ${ }^{\mathrm{a}}$ and Tasminur Mannan Adnan ${ }^{\mathrm{a}^{*}}$
}

${ }^{a}$ Industrial Engineering and Management, University of Oulu, Finland

\section{H R O N I C L E}

Article history:

Received: March 82020

Received in revised format: May

42020

Accepted: May 42020

Available online:

May 42020

Keywords:

Risk Management

Project Management

Risk Management Performance

Measurement

Risk Matrix

Construction Projects

\section{A B S T R A C T}

Distinguishing and diminishing risks in today's projects are crucial for project success. Almost every project is facing several risks throughout the project timeline. Construction projects in Finland are also facing project risks due to the complexity of the project. To minimize the impact of risks, an effective risk management approach must be incorporated into every project which also includes the effectiveness and measurement of its performance. Managing the risks is an important job but measuring the RM performance is crucial. Thus, the objective of this study is to analyze the risk management (RM) and risk management performance measurement (RMPM) through an in-depth empirical analysis of two complex construction projects of Finland. To achieve the objective, a qualitative case study is followed by the authors of this article to identify the RM processes, major and minor risks of the projects, RM strategies to mitigate them and RM performance measurement strategies. Overall, this article provides a comparative analysis of RM and RMPM for construction projects and it can be used as a basis for further research into RM perspective in complex construction projects.

(C) 2020 by the authors; licensee Growing Science, Canada.

\section{Introduction}

The concept of "Risk" is not new. Assessing risk before making decisions was offered by the Athenians a long ago (Bernstein, 1996). However, the concept of "Risk Management" (RM) is comparatively new, about 40-50 years ago (Aven, 2016). In recent years, intense research has been conducted on RM in the field of project management (PM) (Pekkinen \& Aaltonen, 2015). Every business function comes with risks and these risks can affect the business (Acharyya, 2008). Voetsch et al. (2004) also stated in his article that there is a significant relationship between the RM approach and project's success. Such organizations often fail to create value added project RM practices because they end up executing tick-the-box exercise only (Kutsch et al., 2014; Lehtiranta, 2014; Oehmen et al., 2014). Construction projects are no different than that; in fact, construction projects are more unique in a way that they have too many stakeholders, lots of capital investment and complexity. For such constrains, success in construction project is dependent on the quality of preparations and processes. Risk management is such type of process which help project managers and owners to identify, assess and minimize the project risks (Firmenich, 2017). Risk management strat- 
egy can obviously improve the project's success, but it is equally important to maintain the measurements of the RM's performance on regular basis. There are many criteria to measure the performance of organization and measure the efficiency and effectiveness of the activities (Shahbaz et al., 2018). It is said "If you can't measure it, you can't improve it" (Gunasekaran \& Kobu, 2007). Not able to measure the RM's effectiveness during progress of the project may cause project failure (Basova \& Mitselsky, 2011). Without proper evaluation of RM, an organization is unable to track the progress of the risk mitigation; which leads to project failure. Thus, it is very crucial to identify the risks, a proper way to manage them and finally, measure the risk management performance properly. Therefore, the purpose of this article is to focus on the risk management processes and risk management performance measurement evaluation of two large construction projects of Finland. The empirical basis of this article's findings was qualitative interviews and were analyzed and collected through multi-method study. The project managers and owners were interviewed, and two project's risk management and risk management performance measurement practices were analyzed. Further, we analyzed how their practice supports the current RM and RMPM mechanisms.

The article is structured in the following way: Section 2 addresses the insights of RM, risk categories, RM steps and RMPM, Section 3 describes the research method and context. The next section presents our result from the empirical study where we assessed the risk management processes and performance measurement of two construction companies of Finland. Finally, in Section 5 we discuss the implications of the result in managerial field and in section 6 , we will discuss for further research as well.

\section{Theoretical background}

\subsection{Definition of $R M$}

There are many literatures on risk management (RM) where authors defined RM as uncertainty management in a way that risk itself an uncertain thing (Carbone \& Tippett, 2004). The most two popular definitions of RM are published by Project Management Institute (PMI) and Association for Project Management (APM):

"The systematic process of identifying, analyzing and responding to project risk. It includes maximizing the probability and consequences of positive events and minimizing the probability and consequences of adverse events to project objectives" (PMI, 2016).

"A process whereby decisions are made to accept known or assessed risk and/or implementation of actions to reduce the consequences or probability of occurrence" (APM, 2012).

Both organizations defined RM similarly but the major differences between these definitions concerns PMI's consideration of risk as being positive sometimes. According to Jaafari (2001) and Perminova et al. (2008), positive risks, although causing uncertainty, can also maximize success or profit, and should therefore be considered in RM strategies, alongside negative risk (Ward and Chapman, 2003). Many previous publications concur that project failure is closely associated with ineffectual RM in failing projects and some notable project failures due to RM are Yucca Mountain (Swift, 2015), Panama Canal (Alarcón, 2011; Alhojailan, 2012), Millennium Dome (Peter, 2000), Airbus A380 (Shore, 2008). Different scholars have defined RM from different aspects. Table 1 represents some generally accepted aspects of RM.

Table 1

Perspective of RM by different researchers

\begin{tabular}{|c|c|}
\hline Study & RM definition \\
\hline Stranks (1994) & Defines RM in terms of identification, evaluation and control of exposure to each risk that hinders project success. \\
\hline Chong and Brown (2000) & $\begin{array}{l}\text { Risk is a fundamental aspect of RM; the main aim is to minimize or maintain risk at a level that is acceptable for an } \\
\text { enterprise. }\end{array}$ \\
\hline Stephenson et at. (2011) & Describes RM in two dependent variables: risk identification and risk analysis. \\
\hline Loader (2011) & Risk Management is very important for any business, but it doesn't ensure the ultimate success of a project. \\
\hline Loch et al. (2011) & RM is kind of a tool that assists enterprises to confront change. \\
\hline
\end{tabular}




\subsection{Risk Categories}

Project risks are categorized as cost, schedule and performance risk, and also other type of risks such as governance, strategic, operational, market, legal and external hazard risks (Project Management, 2017; Jaber, 2019). Different scholars describe project risk types in different ways depending on the source of nature. Ward and Chapman (2003) found in their article five types of risk sources that cause uncertainty. Miller and Lessard (2001) developed a list of examples of some common risks faced by different project types, according to the nature (social acceptability risk, market risk, social risk, institutional risk, technical risk). A study by IMEC analyzed 60 complex projects where project managers were interviewed and asked to name and rank the risks they faced during the projects. The risks are demand, supply and financial risks (41.7\% of risks); technical, construction and operational risks (37.8\% of risks); regulatory, social acceptability and sovereign risks (20.5\% of risks) (Miller and Lessard, 2001). At the same time Jafaari (2001) identified several risks (political, promotional, technical, financing, operating, schedule, environmental, cost and organizational risks) categories that a project may encounter. Later, Rolstådas et al. (2011) added a new category to this list; called contextual risk. Meanwhile, Artto et al. (2011) divided risks into four types: pure rusk, business risk, financial risk and area-specific risk. Krane et al. (2010) and Thamhain H.J. (2013) also categorized risk into operation, short term strategic, long term strategic and category I - category IV respectively. Fountaine (2015) also divided risks during projects into project risks and technical risks.

\subsection{RM Steps}

In order to handle the complexities and uncertainties of projects there are several steps to be followed in the context of RM. There are many process models of RM described in the literature and there is a strong consensus regarding RM approach (PMBOK). Fone \& Young (2005) stated that the process should include another extra step. According to them, the steps are: RM mission identification, Risk and uncertainty assessment, Risk control, Risk financing and Program administration. Chapman and Ward (2003) expressed a generic framework named "SHAMPU" which contains nine steps: define, focus, identify, structure, ownership, estimate, evaluate, plan and manage. D. van Well-Stam et al. (2004) also described the RM steps in a similar way by splitting the RM process into nine steps. D. Van emphasized that after performing risk analysis, the following evaluation and control phase should continue on a regular basis. Another popular framework named Active threats opportunity management (ATOM) by Hillson and Simon (2007), where he mentioned that threats and opportunities can be controlled by identifying and assessing risk during two-day workshops. Kahkonen and Artto (2008) also developed a holistic RM process model where they divided RM steps into core and accessory steps. This process focuses on continuous risk registry updates and environment scanning (Kahkonen \& Artto, 2008).

\subsection{Risk Management Performance Measurement}

Performance measurement is a process of quantifying the efficiency and effectiveness of past actions (Neely et al., 2007). Moullin (2002) stated in his research that performance measurement is a process in which the management of the organization and the customer valuation are evaluated. Goh (2012) stated that the main aim of performance measurement is to make the organization more efficient while improving its performance. Measurement must start immediately once the criteria have been selected and should continue throughout the project (Bradley et al., 2010). Performance management has four main components: duty, strategy goal, performance goal and performance index (Seon-Gyoo kim, 2010). Among them, the four most used and popular RM performance measurement methods for large construction projects are: BSC, EVMS, KPI and RMI (Brandon, 2005). Balance Score Card (BSC) was introduced by Kaplan and Norton (1991). Though it is a strategic management method, it is also suitable for analyzing traditional finance and accounting performance. According to Kaplan and Norton, BSC has four perspectives and the goals and 
measure changes with the perspectives. Earn value management system (EVMS) is the most extensively used performance measurement method. According to Fleming and Koppelman (2005), and PMI (2005), EVMS has three main variables: planned value (PV) budgeted value for the project, actual cost (AC) of the work done, earned value (EV) of work completed (EVM, 2017). There are also four types of variance analysis for EVMS (Fernando Acebes et al., 2013) that is shown in Table 2.

Table 2

EVMS variance analysis (PMI, 2011)

\begin{tabular}{|c|c|c|c|}
\hline Cost Variance $(\mathrm{CV})$ & Schedule variance (SV) & Cost performance Index (CPI) & Schedule Performance Index (SPI) \\
\hline $\mathrm{CV}=\mathrm{EV}-\mathrm{AC}$ & $\mathrm{SV}=\mathrm{EV}-\mathrm{PV}$ & $\mathrm{CPI}=\mathrm{EV} / \mathrm{AC}$ & $\mathrm{SPI}=(\mathrm{EV} / \mathrm{PV})$ \\
\hline $\begin{array}{l}\mathrm{CV}=0 \text {; project is on } \\
\text { budget, } \mathrm{CV}=(-) \mathrm{ve} \text {; } \\
\text { project is over budget, } \\
\mathrm{CV}=(+) \text { ve; project is } \\
\text { under budget }\end{array}$ & $\begin{array}{l}\mathrm{SV}=0 ; \text { project is on } \\
\text { schedule, } \mathrm{SV}=(-) \mathrm{ve} \text {; project } \\
\text { is over schedule, } \mathrm{SV}=(+) \mathrm{ve} \text {; } \\
\text { project is under schedule }\end{array}$ & $\begin{array}{l}\mathrm{CPI}=>1 \text {; project is favorable } \\
\text { condition, } \mathrm{CPI}<1 \text {; project is in } \\
\text { unfavorable condition }\end{array}$ & $\begin{array}{l}\mathrm{SPI}=>1 \text {; project is favorable condition, } \\
\mathrm{SPI}<1 \text {; project is in unfavorable condition }\end{array}$ \\
\hline
\end{tabular}

Key performance Index (KPI) is mainly used to measure the performance of construction business, but Carreño et al. (2007) stated in his article that it can also be used to measure the RM system performance and success. When developing a KPI for project's performance, four characteristics must be taken into consideration: tangibility, flexibility, standardization and objective focus (KPI, 2017). Risk Management Index (RMI) is another method which is based on four indicators and those are: risk identification (RMIRI), risk reduction index (RMIRR), disaster management index (RMIDM), government and financial protection index (RMIFP) (Carreno et al., 2007). RMI is the average of these four indicators:

$$
R M I=(R M I R I+R M I R R+R M I D M+R M I F P) / 4
$$

The performance of each indicator can be ranked as low, incipient, significant, outstanding or optimal; numbered from 1 (low) to 5 (optimal) (Carreño et., 2007).

\section{Methodology}

Research Methodology acts as a glue which holds research together in a perfect rigid shape, providing a framework to carry out the research in its entity (Herbst \& Coldwell, 2004). This study focuses on analyzing the RM approaches and their RMPM in two large construction projects. A qualitative approach is followed in pursuing this research as qualitative research is a systematic approach which illustrates life experience and related situation provide its meaning (Burns and Grove, 2003). The rationale behind selecting a qualitative approach for this research is that this research focuses on case studies with different risk identification strategies. As their impact and performance management plans are analyzed, the data regarding the risk identification and how they were tackled in the projects is most appropriately collected through verbal and questionnaire means. Data was collected through face-to-face interviews with two construction projects: The Tampere Rantatunneli Project (TRP) and Tampere Tramway Project (TTP). In TRP, an underground tunnel was built excavating rock in the middle of the Tampere city. TTP is a $24 \mathrm{~km}$ long tramway that's currently under construction in Tampere city. Data for TTP case study was collected through face-to-face interviews which were semi-structured as a list of questions. The interviews were recorded through audio tape and was later transcribed for data analysis. Data for TTP was collected through a questionnaire and it was very helpful as in this form, the participant has their own freedom and time to give answers according to their own pace. The data that was recorded and transcribed from the interview and questionnaires, was analyzed through a thematic content analysis method. This involves organizing the data into different categories based on the relevant themes and features (Alholjalin, 2012). At first the data from interviews was first categorized based on the qualitative data given by the interviews, then categorized into RM steps, risk identification, major and minor risks and performance measurement of those risks. Finally, 
based on the categorized data, project complexity was validated, a RM process was drawn up, the impact of major and minor risks was calculated, and a risk matrix was drawn. Thus, the categorized data helped us with the interpretation of collected data.

\section{Results}

\subsection{Project Risk Management (PRM)}

In both projects, the alliances followed RM process in two phases: development phase and implementation phase. Risk identification, risk analysis, risk distribution and risk action were followed in both phases as a cont. process throughout the TRP project. Meanwhile in the TTP, the RM was planned for development phase only. In the development phase, the RM team used a Monte Carlo Simulation Model with a view to calculate the risk value and risk level. Figure 1 shows the $\mathrm{RM}$ process of two individual projects.
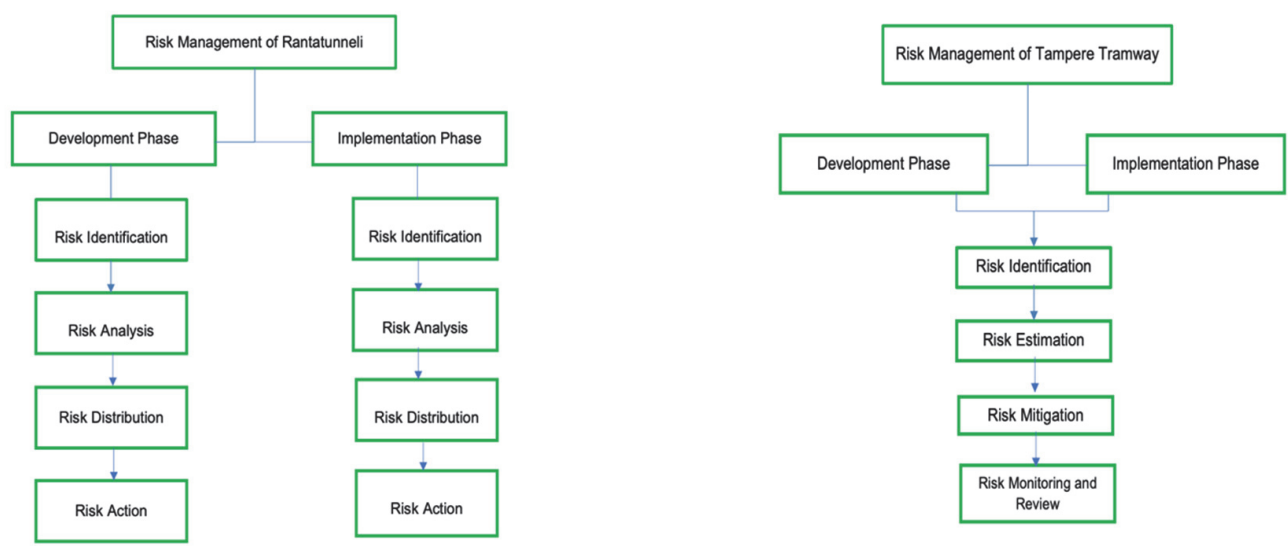

Fig. 1. RM processes of TRP and TTP

\subsection{Categorizing the Project Risks}

In the TRP, risks were categorized based on the work of the specialist groups and phases in which the risks were identified in the development and implementation phases. The identified risks were categorized based on PM skills or risks by specific technological discipline. In the TTP, many of the risks were classified and categorized during the development phase, and it was continuing to emerge day-by-day. The identified risks were mainly related to cost and constructability. Later, in the implementation phase, risks related to work safety, project, cost, schedule and operation are being identified. Table 3 shows different risks and their category in both projects.

Table 3

Risk Name and Risk Categories of TRP and TTP

\begin{tabular}{|c|c|c|c|}
\hline \multicolumn{2}{|c|}{ Tampere Rantatunneli Project (TRP) } & \multicolumn{2}{|c|}{ Tampere Tramway Project (TTP) } \\
\hline Risk Name & Risk Category & Risk Name & Risk Category \\
\hline Polluted soil & Technical risk & Active urban environment & External Risk \\
\hline Quality of rock & Technical risk & Project permission & External Risk \\
\hline Ground water level control & Technical risk & Construction collapse & Operational Risk \\
\hline People acceptance & Social risk & Contaminated soil & Operational Risk \\
\hline Tunnel malfunction & Operational risk & Worker accident & Work safety Risk \\
\hline Staff turnover & Schedule risk & Staff turnover & Management Risk \\
\hline Breach schedule & Schedule Risk & Breach schedule & Schedule risk \\
\hline Material price increase & Market Risk & Material price increase & Cost/Market risk \\
\hline Subcontractor failure & Market Risk & Subcontractor failure & Market risk \\
\hline Political oppose & Political Risk & Adverse weather & Environmental risk \\
\hline
\end{tabular}

\subsection{Risk matrix}

To access the risk matrix, at first the risk severity is assessed. A risk grading scale is used (Table 4) in which a score of 1 represents the lowest probability and impact on the project and score of 5 represents the highest probability and most major impact on the project. 
Table 4

Risk Grading scale

\begin{tabular}{|c|c|c|}
\hline Grading Value & Probability of occurrence & Impact size \\
\hline 1 & Almost impossible & Insignificant \\
\hline 2 & Improbable & Less significant \\
\hline 3 & Possible & Significant \\
\hline 4 & Probable & Very significant \\
\hline 5 & Almost certain & Critical \\
\hline
\end{tabular}

Using the risk grading scale, RPN (Risk priority number) was calculated in Table 5 to find out the seriousness of the risk, where RPN= Probability of occurrence X Impact.

Table 5

Risk Severity Calculation of TRP and TTP

\begin{tabular}{|c|c|c|c|c|c|c|c|c|}
\hline \multirow{2}{*}{$\begin{array}{l}\text { Risk } \\
\text { No. }\end{array}$} & \multicolumn{4}{|c|}{ Tampere Rantatunneli Project (TRP) } & \multicolumn{4}{|c|}{ Tampere Tramway Project (TTP) } \\
\hline & Risk & Probability & Impact & RPN & Risk & Probability & Impact & RPN \\
\hline R1 & Polluted soil & 5 & 4 & 20 & $\begin{array}{l}\text { Active urban } \\
\text { environment }\end{array}$ & 5 & 4 & 20 \\
\hline $\mathrm{R} 2$ & Quality of rock & 3 & 4 & 12 & Project permission & 4 & 4 & 16 \\
\hline R3 & $\begin{array}{c}\text { Ground water level } \\
\text { control }\end{array}$ & 4 & 4 & 16 & $\begin{array}{c}\text { Construction } \\
\text { collapse }\end{array}$ & 4 & 4 & 16 \\
\hline R4 & People acceptance & 3 & 4 & 12 & Contaminated soil & 3 & 3 & 9 \\
\hline R5 & Tunnel malfunction & 2 & 5 & 10 & Worker accident & 3 & 4 & 12 \\
\hline R6 & Staff turnover & 2 & 3 & 6 & Staff turnover & 2 & 3 & 6 \\
\hline R7 & Breach schedule & 1 & 4 & 4 & Breach schedule & 2 & 4 & 8 \\
\hline $\mathrm{R} 8$ & Material price increase & 2 & 4 & 8 & $\begin{array}{l}\text { Material price } \\
\text { increase }\end{array}$ & 2 & 4 & 8 \\
\hline R9 & Subcontractor failure & 1 & 3 & 3 & $\begin{array}{l}\text { Subcontractor } \\
\text { failure }\end{array}$ & 1 & 3 & 3 \\
\hline $\mathrm{R} 10$ & Political oppose & 3 & 3 & 9 & Adverse weather & 4 & 3 & 12 \\
\hline
\end{tabular}

The risk matrix for TRP and TTP were developed using Table 4 and Table 5. Fig. 2 shows the risk matrix for TRP and TTP respectively. In TRP, the polluted soil and Ground water level control (R1 \& R3) are on high risk whereas in TTP; active urban environment, project permission and construction collapse (R1, R2 \& R3) are on high risk.
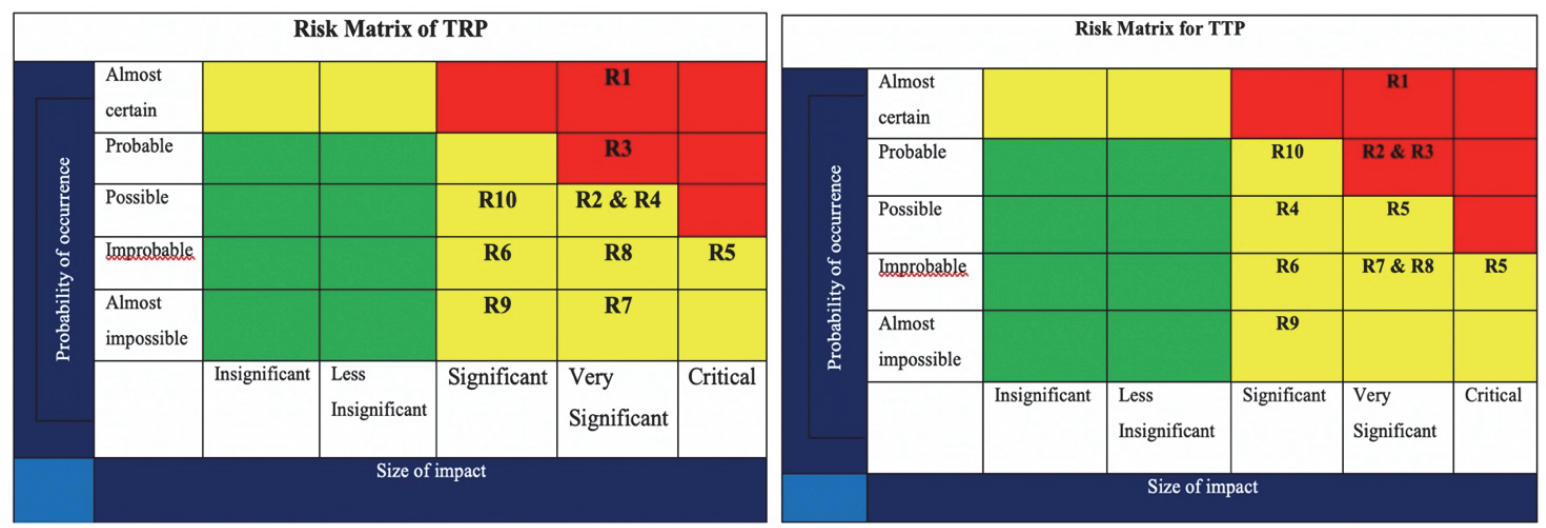

Fig. 2. Risk Matrix for TRP and TTP

\subsection{Risk Management Performance Measurement (RMPM)}

The TRP team did not set any specific criteria to measure their RMPM; rather it set project success criteria, through which to judge its RM performance. Though they usually used to judge RM performance effectiveness through tracking the identified risk and managed risk. This risk tracking process also used as the continuous RM improvement tool as management was able to identify any gap and later improve that lacking. The main criteria it used for measuring success were TOC (target outturn cost), KPI for KRA (key performance index for key result area) and positive and negative modifiers. The KPI that was set for measuring success were schedule, safety, usability and public image. At the project end, success was achieved in all four areas of the KPI. The TOC for project 
implementation was set by the alliances in the development phase in a way that the leftovers will be split between the alliance partners. The final outturn cost was Euro 195,938, 844 and the cost was Euro 192,183,048. The TOC undercut was Euro 3,755,796 which was due as an incentive bonus. Figure 3 represents the whole scenario of how TRP determines their RMPM which is totally based on the final incentives.

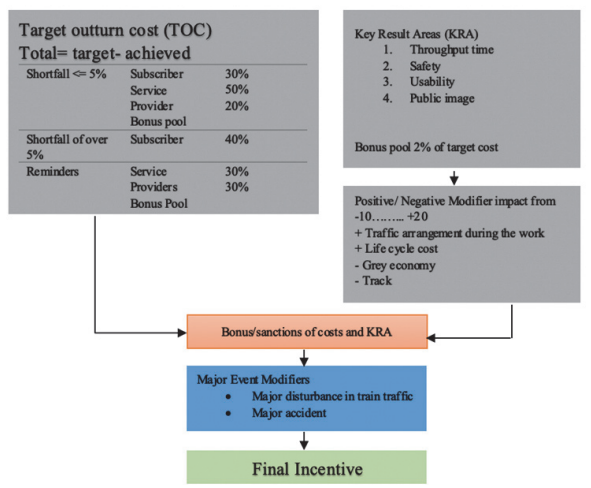

Fig. 3. Performance measurement system TRP (Value for Money, 2018)

The alliance team set some key result area (KRA) which are judged by comparing the minimum performance target with the industry average. Table 6 shows that for specific KRA's (schedule, safety, usability, public image), there is a KRA point for each KRA. The indicator to measure each of the KRA was set from -100 to +100 points (Up to +100 points for breakthrough and outstanding performance, up to -100 points for total failure regarding meeting minimum requirement criteria, 0 score if the meet minimum requirement criteria are met).

Table 6

'KPI for KRA' for TRP

\begin{tabular}{|c|c|c|c|}
\hline KRA & Target (0 level) & Result & $\begin{array}{c}\text { KRA } \\
\text { points }\end{array}$ \\
\hline Schedule & Complete by $15^{\text {th }}$ May, 2017 & Completed $15^{\text {th }}$ November, 2016 & 100 \\
\hline \multirow[t]{2}{*}{ Safety } & $14-16$ & 11.9 & 15.1 \\
\hline & $160-200$ & 56 & 84.4 \\
\hline Usability & Constant traffic flow with some disruptions & 3 minor disruptions & 94 \\
\hline Public Image & $85-90$ & 88 & 0 \\
\hline
\end{tabular}

The positive and negative modifier criterion in Table 7 was used to provide the reward or give penalties to the alliances for those tasks which were very crucial for the project's success. To set indicator values for this criterion would not have been practical. A positive modifier could add up to 20 points whereas a maximum of 10 points could be deducted for a negative modifier.

Table 7

Positive and negative modifiers for TRP

\begin{tabular}{|c|c|c|c|c|c|c|c|}
\hline $\begin{array}{c}\text { Pos. } \\
\text { Modifier }\end{array}$ & Target & Result & KRA & Neg. Modifier & Target & Result & $\overline{\text { KRA }}$ \\
\hline $\begin{array}{l}\text { Traffic disturb- } \\
\text { ance during con- } \\
\text { struction }\end{array}$ & $\begin{array}{l}\text { KVLsame as before } \\
\text { the project } \\
\text { KVL max- } 7 \% \text { com- } \\
\text { pared to before the } \\
\text { project }\end{array}$ & $\begin{array}{l}\text { KVL }-1 \% \text { less than } \\
\text { before the project }\end{array}$ & +5 & $\begin{array}{c}\text { Highway 12 } \\
\text { traffic disturb- } \\
\text { ance }\end{array}$ & $\begin{array}{l}\text { Traffic stopped } \\
\text { for 6-24 hour }\end{array}$ & None & 0 \\
\hline Damages & $\begin{array}{c}\text { Below } 0.75 \% \text { of the } \\
\text { TOC }\end{array}$ & $0.2 \%$ of the TOC & +5 & $\begin{array}{l}\text { Train traffic } \\
\text { disturbance }\end{array}$ & $\begin{array}{l}\text { Train stopped 6- } \\
24 \text { hour }\end{array}$ & None & 0 \\
\hline $\begin{array}{l}\text { Significant acco- } \\
\text { lade }\end{array}$ & Award received & $\begin{array}{l}\text { RIL award winning } \\
\text { site } 2016 \\
\text { PRY award winning } \\
\text { project } 2017\end{array}$ & +5 & Grey economy & $\begin{array}{l}\text { Observed once } \\
\text { Observed once }\end{array}$ & None & 0 \\
\hline Life cycle cost & $\begin{array}{c}\text { Impact over Euro } \\
100,000 \text { p.a }\end{array}$ & $\begin{array}{l}\text { Below Euro } 100,000 \\
\text { p.a }\end{array}$ & 0 & & & & \\
\hline
\end{tabular}

Based on the calculated weighted KRA, contractors received Euro 4,681,509 as an incentive bonus. This was split so that LMK Infra Oy received Euro 4,100,299, A-insinoorit Oy received Euro 331,008 and S\&R Oy received Euro 250,202. In total, the project performance was significantly 
higher than expected, as it fulfilled all of the key objectives. On the contrary, the TTP's project implementation phase started in 2017. The project team is defining its RM and RMPM plan continuously by measuring the number of identified risks and number of risks eliminated, using a risk level calculation. No fixed KPI for measuring the RM performance has been set so far. Presently, the team is temporarily judging its RMPM through comparison of the number of open hazards with the number of controlled or hazards. In its current RMPM system, the project team follows the steps presented in Fig. 4.

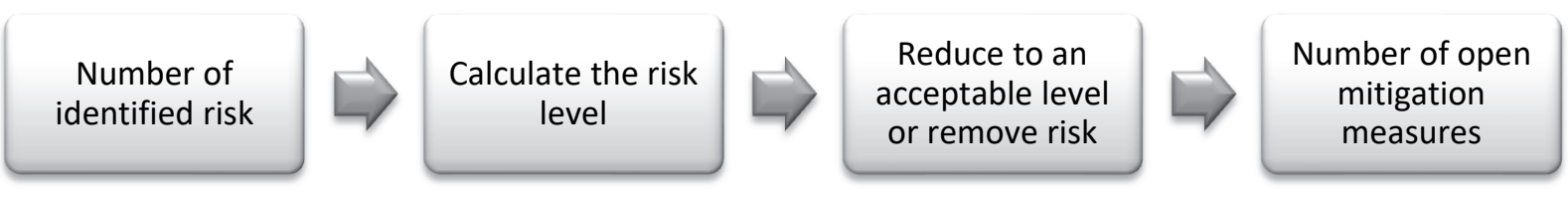

Fig. 4. RMPM process steps of TTP

\section{Discussion}

The practical case analysis used in this project helped to demonstrate the benefits of RM in construction projects. In case of RM in TRP, it was easier to identify the potential risks through the alliance project team than it would have been for partners to do separately. The alliance team followed the "Big Room" concept where they joined in an open space and discussed about PRM issues. The project finished six months ahead of schedule and TOC was less than predicted. Pain/Gain method was used between all parties instead of one single party only. There were some arguments between team members during PM discussion about RM managing issues, such as, identifying methods of risk, risk mitigation ways, risk responsibilities, contrast decisions with risk accepting, removing, transferring and fixing the risk reserve budget etc. In spite of the arguments, after a certain period, teams were agreed upon a specific method. On the other hand, the TTP is comparatively new and the questionnaire interview showed that the initial planning concerning the project timeline, budget risk and uncertainty management and QC was done by the team and the project team has successful progress in terms of RM, timeline and cost controlling till now. Both project teams put high emphasis on the risk management issues.

The RM team of both projects followed the basic RM process for risk identification, evaluation, mitigation and monitoring which is also suggested by previous researchers (Ward \& Chapman, 2003; Kahkonen \& Artto, 2008; PMBOK,2016). After the risk identification phase, the Monte Carlo Simulation Method was used to calculate the risk impact level. From the analysis, it's found that risk identification is the most crucial stage on both development and implementation phase. Apart from that, every personnel of the team were aware of the $\mathrm{Rm}$ issues and responsible to track and identify any potential risk. Moreover, TRP maintained a balanced risk reserve budget in their final budget plan. The RM team of TRP successfully identified the risks and managed them in an efficient way as they used to track risk mitigation in a periodical manner. Thus, this research findings support that with a properly planned and balanced RM approach, any complex construction project's risk can be managed efficiently and effectively which lead to project success.

In the literature, there are very few methodologies regarding RMPM. Amongst them, the most commonly used RMPM for large construction projects are Balanced Score Card (BSC), Earned Value Management System (EVMS), Key Performance Indicator (KPI) and Risk Management Index (RMI), with KPI being the most commonly used. In this research, TRP did not directly specify any indicators rather it set some goals, along with some fixed KPI, TOC, positive and negative modifiers. The reason to overlook the RMPM in TRP was because they have a project success measuring criteria and the team might not find the necessity to implement any separate criteria. Another reason might be their well-balanced risk tracking and mitigation process. Though their RM process was successful without having any RMPM, still RMPM is on the table of improvement. On the other hand, TTP is yet to determine KPI parameters to assess its RMPM. The team did not directly specify 
any indicators or performance assessment criteria for the RMPM, as this project is on its initial stage, but it is following risk mitigation measures with the number of open hazards being compared with the number of controlled or removed hazards. To measure the RMPM, the RM management program might include with the managements KPI and also it might be included in organization's compliance audit. Some KPI might be implemented to measure the RM performance through establishing objectives and performance measures which presented in Table 8 with KPI example (Section 2.4).

Table 8

KPI for RM performance measurement

\begin{tabular}{|c|c|c|}
\hline Objectives & Performance Measures & KPI \\
\hline All personnel should be trained under RM program by Q3 & \% personnel trained by Q3 & $95 \%$ by Q3 \\
\hline Risk registers need to be developed for all function areas by Q3 & $\%$ functional areas developed risk registers & $98 \%$ by Q3 \\
\hline $\begin{array}{l}\text { All new risks should be included in the risk register and as- } \\
\text { signed the responsible person within the } 24 \text { hour of risk identi- } \\
\text { fication }\end{array}$ & $\begin{array}{l}\% \text { new risk included in the risk register by } 24 \\
\text { hour of risk identification }\end{array}$ & $100 \%$ \\
\hline All risks need to be managed by specific timeline & $\%$ risk managed by the timeline & $98 \%$ \\
\hline
\end{tabular}

\section{Conclusion}

The prime goal of this research article is to provide a deep understanding of the role of project RM in construction projects through presenting risk identification, prioritization and management of implementation, and finally, the importance of measuring the effectiveness and efficiency of RM performance. In this research, the empirical analysis of RM and RMPM was conducted on qualitative feedback concerning two large construction projects. The research was carried out by performing an extensive literature review on RM and measurement of RM performance, followed by real case analysis through a semi-structured interview and questionnaire. The literature review shows that project failure has been increasing for the last few decades (Raz et al., 2002; Flyvbjerg et al., 2003; Mulcahy, 2003) as general RM standards are not always sufficient due to complexity (Atkinson et al., 2006). RM has become an integral part of PM in construction projects as construction projects suffer the highest rest of failure. In-depth, risk analysis is an effective plan an contribute significantly towards project success. In order to be effective, a RM plan should also include RM performance measurement (Basova \& Mitselsky, 2011; Goh, 2012). RM alone cannot guarantee project success, as without evaluation of current performance, the project manager cannot know the true scenario of the RM plan. Ultimately, an efficient and effective RM strategy with RMPM helps organizations achieve success in their projects, enables efficient use of resources and maximizes profitability.

This study reveals the different methods in organizing RM and evaluate the RMPM on construction projects and their importance on the projects. The findings from this study point out the alliance contracting impacts on RM, effective use of RM tools and the importance of RMPM. Thus, the findings and analysis of this study will help other project managers to imply practically in the following manners- (1) forming the alliance contract for large, complex projects for the efficient use of resources, (2) focusing on the RM process and the decision by judging project difficulty level as large construction projects possess high risk and thus RM process needs more close attention, (3) making a well-balanced RM plan with regular tracking of the identified risks as it reduces the risk occurrence probability, (4) Having a well-balanced risk reserve cost in the final budget, (5) maintaining the risk workshop concept periodically to get and tract about any new emerging risk in order to have the project team well informed about those, (6) giving the risk tracking and managing responsibility to every person of the project team, (7) focusing on implementing RM performance measuring criteria to make sure efficient and effective uses of RM resources. Project managers must make sure a well-balanced RM plan and RMPM in order to get the desired project success. Even though every large project, nowadays, give utmost focus on the RM; RMPM must also get incorporated with those RM plan to get most efficient project result. 
This research was performed using a qualitative approach where interviews were carried out. The Data was interpreted and analyzed, which can lead to subjective or biased interpretation. In both cases, interviews were taken from the project owner or manager, which may lead to limited information being revealed. Whilst an attempt was made to limit bias, it cannot be completely ruled out. It was also not possible to conduct more interviews because of organization's protocols. Additionally, being present with the project for a long time during the project's development and implementation phase might result in more effective observation and more accurate results. Furthermore, the empirical analysis of this research only concerned on construction projects. Empirical analysis of projects from different industry of different country might give different perspective. In this article, one of the case projects analyzed is only in the early phase of construction, this information about its RM performance measurement plan was limited.

For further improvement of this study, more case could be included for empirical analysis and compared to other complex projects, such as technological projects. Similar study could also be conducted including multiple international stakeholders, which may give a different perspective and reveal additional issues. Another scope might be to use both qualitative and quantitative approaches together to increase the reliability and impact of the study. Further research should continue, specifically, on developing RM performance management methods on complex projects as there is little study on this topic. Establishing specific and efficient KPI for measuring RM performance for construction projects would be another scope for further research.

\section{References}

Acebes, F., Pajares, J., Galán, J. M., \& López-Paredes, A. (2013). Beyond earned value management: A graphical framework for integrated cost, schedule and risk monitoring. Procedia-Social and Behavioral Sciences, 74, 181-189.

Acharyya, M. (2008). In measuring the benefits of enterprise risk management in insurance: An integration of economic value added and balanced score card approaches. Society of Actuaries, Working paper.

Alarcón, L. F., Ashley, D. B., de Hanily, A. S., Molenaar, K. R., \& Ungo, R. (2011). Risk planning and management for the Panama Canal expansion program. Journal of Construction Engineering and Management, 137(10), 762-771.

Alhojailan, M. I. (2012). Thematic analysis: A critical review of its process and evaluation. West East Journal of Social Sciences, 1(1), 39-47.

Artto, K., Martinsuo, M., \& Kujala, J. (2011). Project Business. Helsinki, Finland.

Association for Project Management (APM), (2012) Project Risk Analysis and Management Guide. APM Publishing Limited, High Wycombe, Buckinghamshire

Atkinson, C., Cuske, C., \& Dickopp, T. (2006, October). Concepts for an ontology-centric technology risk management architecture in the banking industry. In 2006 10th IEEE International Enterprise Distributed Object Computing Conference Workshops (EDOCW'06) (pp. 21-21). IEEE.

Aven, T. (2016). Risk assessment and risk management: Review of recent advances on their foundation. European Journal of Operational Research, 253(1), 1-13.

Basova, M., Mitselsky, A., Risk Management KPIs: Efficiency Tool or Formality?, Enterprise Risk Management Symposium, Society of Actuaries.

Bernstein, P. L., \& Bernstein, P. L. (1996). Against the gods: The remarkable story of risk (pp. 1269-1275). New York: Wiley.

Bradley, E. H., Pallas, S., Bashyal, C., Berman, P., \& Curry, L. (2010). Developing strategies for improving health care delivery: Guide to Concepts, Determinants, Measurement, and Intervention Design.

Brandon, D. M. (Ed.). (2005). Project management for modern information systems. IGI Global

Burns, W., \& Grove, S. K. 2003. Witch Hunts in Europe and America. An Encyclopedia, London.

Carbone, T. A., \& Tippett, D. D. (2004). Project risk management using the project risk FMEA. Engineering management journal, 16(4), 28-35. 
Carreño, M. L., Cardona, O. D., \& Barbat, A. H. (2007). A disaster risk management performance index. Natural Hazards, 41(1), 1-20.

Chong, Y. Y., \& Brown, E. M. (2000). Managing project risk: Business risk management for project leaders. Financial Times/Prentice Hall.

Earned Value Management System, (2017, 07 July). Retrieved from http://apmg-international.com/article/what-earned-value-management-and-why-it-important

Firmenich, J. (2017). Customisable framework for project risk management. Construction Innovation.

Fleming, Q. W., \& Koppelman, J. M. (2016, December). Earned value project management. Project Management Institute.

Flyvbjerg, B. (2003). Rationality and Power. Teoksessa Campbell, Scott and Susan S. Fainstein (Eds.) Readings in Planning Theory. 319-329.

Fone, M., \& Young, P. C. (2005). Managing risks in public organizations. Perpetuity Press.

Fountaine, M. (2015). Enterprise Risk Management: A Common Framework for the Entire Organization. Butterworth- Heinemann, Newton, MA, USA

Goh, S. C. (2012). Making performance measurement systems more effective in public sector organizations. Measuring Business Excellence.

Gunasekaran, A., \& Kobu, B. (2007). Performance measures and metrics in logistics and supply chain management: a review of recent literature (1995-2004) for research and applications. International journal of production research, 45(12), 2819-2840.

Herbst, F., \& Coldwell, D. (2004). Business research. Juta and Company Ltd.

Hillson, D., \& Simon, P. (2007). Practical project risk management: The ATOM methodology. Management Concepts.

How to Develop KPIs (2017, May 13). Retrieved from http://kpi.org/KPI-Basics/KPI-Development

Institute of Risk Management (2011), Risk Appetite and Tolerance Guide Paper. 2011. Available: http://theirm.org/publications/documents/IRMRiskAppetiteFullweb.pdf [Accessed February 2018]

Jaafari, A. (2001). Management of risks, uncertainties and opportunities on projects: time for a fundamental shift. International journal of project management, 19(2), 89-101.

Jaber, A. Z. (2019). Assessment Risk in Construction Projects in Iraq Using COPRAS-SWARA Combined Method. Journal of Southwest Jiaotong University, 54(4).

Kähkönen, K. and Artto, K. (2008) Concepts and Processes. In: Kähkönen, K., Artto, K., Karjalainen, J., Martinsuo, M. and Poskela, J., Eds., Management of Uncertainty, Helsinki University of Technology, Helsinki, 8-23.

Kaplan, R. S., \& Norton, D. P. (2007). Balanced scorecard. In Das Summa Summarum des Management (pp. 137-148). Gabler.

Kim, S. G. (2010). Risk performance indexes and measurement systems for mega construction projects. Journal of Civil Engineering and Management, 16(4), 586-594.

Krane, H. P., Rolstadås, A., \& Olsson, N. O. (2010). Categorizing risks in seven large projectsWhich risks do the projects focus on? Project Management Journal, 41(1), 81-86.

Kutsch, E., Browning, T. R., \& Hall, M. (2014). Bridging the risk gap: The failure of risk management in information systems projects. Research-Technology Management, 57(2), 26-32.

Lehtiranta, L. (2014). Risk perceptions and approaches in multi-organizations: A research review 2000-2012. International Journal of Project Management, 32(4), 640-653.

Loader, D. (2011). Operations risk: managing a key component of operational risk. Elsevier.

Loch, C. H., DeMeyer, A., \& Pich, M. (2011). Managing the unknown: A new approach to managing high uncertainty and risk in projects. John Wiley \& Sons.

Miller, R., \& Lessard, D. (2001). Understanding and managing risks in large engineering projects. International Journal of Project Management, 19(8), 437-443.

Moullin, M. (2007). Performance measurement definitions. International journal of health care quality assurance.

Mulcahy, R. (2003). Risk Management: Tricks of the Trade ${ }^{\circledR}$ for Project Managers: a Course in a Book [trademark Symbol]. RMC Pub. 
Neely, A., Kennerley, M., \& Adams, C. (2007). Performance measurement frameworks: a review. Business Performance Measurement, 143-162.

Oehmen, J., Olechowski, A., Kenley, C. R., \& Ben-Daya, M. (2014). Analysis of the effect of risk management practices on the performance of new product development programs. Technovation, 34(8), 441-453.

Pekkinen, L., \& Aaltonen, K. (2015). Risk management in project networks: an information processing view. Technology and Investment, 6(01), 52.

Perminova, O., Gustafsson, M., \& Wikström, K. (2008). Defining uncertainty in projects-a new perspective. International journal of project management, 26(1), 73-79.

Peter, J. (2000). Case study: The Millennium Dome- Marvel or disaster? Tourism and Hospitality Research, 2(20, 171-182

Project Management Institute, (2016). A Guide to the Project Management Body of Knowledge (PMBOK). Newton Square. Project Management Institute

Project Management Institute. (2011). Practice standard for earned value management. Project Management Institute, Incorporated.

Raz, T., Shenhar, A. J., \& Dvir, D. (2002). Risk management, project success, and technological uncertainty. $R \& D$ Management, 32(2), 101-109.

Rolstadås, A., Hetland, P. W., Jergeas, G. F., \& Westney, R. E. (2011). Risk navigation strategies for major capital projects: Beyond the myth of predictability. Springer Science \& Business Media.

Shahbaz, M. S., Rasi, R. Z. R. M., Zulfakar, M. H., Ahmad, M. B., Abbas, Z., \& Mubarak, M. F. (2018). A novel metric of measuring performance for supply chain risk management: drawbacks and qualities of good performance. Journal of Fundamental and Applied Sciences, 10(3S), 967988.

Shore, B. (2008). Systematic biases and culture in project failures. Project Management Journal, 39(4), 5-16.

Stephenson, Z., Fairburn, C., Despotou, G., Kelly, T., Herbert, N., \& Daughtrey, B. (2011). Distinguishing Fact from fiction in a system of systems safety case. In Advances in Systems Safety (pp. 55-72). Springer, London.

Stranks, J. W. (1994). The handbook of health and safety practice. Financial Times Management.

Swift, P. N. (2015). The Proposed Yucca Mountain Repository: A Case Study (No. SAND201510017PE). Sandia National Lab. (SNL-NM), Albuquerque, NM (United States).

Thamhain, H. (2013). Managing risks in complex projects. Project management journal, 44(2), 20 35.

Types of risk in Project Management (2017, June 3). Retrieved from, https://project-management.com/types-of-risk-in project-management/

van Well-Stam, D., Lindenaar, F., \& van Kinderen, S. (2004). Project risk management: An essential tool for managing and controlling projects. Kogan Page Publishers.

Voetsch, R. J., Cioffi, D. F., \& Anbari, F. T. (2004, August). Project risk management practices and their association with reported project success. In Proceedings of 6th IRNOP Project Research Conference, Turku, Finland (pp. 680-697).

Ward, S., \& Chapman, C. (2003). Transforming project risk management into project uncertainty management. International Journal of Project Management, 21(2), 97-105

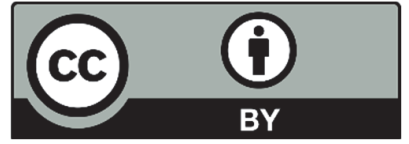

(C) 2020 by the authors; licensee Growing Science, Canada. This is an open access article distributed under the terms and conditions of the Creative Commons Attribution (CC-BY) license (http://creativecommons.org/licenses/by/4.0/). 